\title{
An unusual renal accessory artery originating from the thoracic aorta and its potential clinical implications
}

\author{
Elvira Talović, Alma Voljevica \\ ${ }^{1}$ Institute of Anatomy "Prof. Dr. Hajrudin \\ Hadžiselimović”, Faculty of Medicine \\ University of Sarajevo, Sarajevo \\ Bosnia and Herzegovina \\ Corresponding author: \\ Alma Voljevica \\ Institute of Anatomy \\ "Prof. Dr. Hajrudin Hadžiselimović" \\ Faculty of Medicine \\ University of Sarajevo \\ Čekalusa 90 \\ 71000 Sarajevo \\ Bosnia and Herzegovina \\ alma.voljevica@yahoo.com \\ Tel.: + 38733665949 \\ Fax.: + 38733203670
}

\begin{abstract}
We report a case of an unsual anatomical vascular blood supply to the right kidney. In an analysis of kidneys, by dissection of 39 foetuses, additional renal arteries were found in 18 cases (46.15\%). In only one case $(2.5 \%)$ was it noticed that the right kidney was supplied with blood by three renal arteries, one main and two additional arteries. One of the additional arteries, marked as the upper pole artery of aortic origin, separated from the thoracic aorta at the level of T11 (the eleventh thoracic rib), $1.5 \mathrm{~cm}$ above the truncus coeliacus. This artery, after passing through the diaphragm, entered the renal hilus at its upper part and served to vasculate that part of the kidney. Conclusion. The importance of this study is seen in the fact that anatomic knowledge of variations in the vascularization of the kidneys is of exceptional practical importance. Also, this information may concern transplant surgeons involved in living donor nephrectomies.
\end{abstract}

Key words: Additional renal arteries, Anatomy, Dissection method.

\section{Introduction}

The long-held opinion, that there is usually only one renal artery in the vascularization of a kidney, has been replaced with a new one which holds that in $9-76 \%$ of cases vascularization of the kidneys is by additional arteries from various sources (1). With the increase in the number of kidney transplants indicated, vascular reconstruction, surgical procedures on the kidneys and the development of new digital radiological methods, the knowledge of variations in renal vascularization is becoming increasingly important from day to day.

\section{Material and methods}

Using anatomical dissection, an analysis of kidneys was carried out on 39 human fe- tuses. Legal and ethical considerations were consistent with the Helsinki Declaration and the approval of the Ethics Committee of the Medical Faculty in Sarajevo.

\section{Results}

Additional renal arteries were found in 18 cases of 39 human fetuses (46.15\%). In only one case $(2.5 \%)$ was it noticed that the right kidney was supplied with blood by three renal arteries, one main and two additional arteries. One of the additional arteries, marked as the upper pole artery of aortic origin, separated from the thoracic aorta at the level of $\mathrm{T} 11$ (the eleventh thoracic rib), $1.5 \mathrm{~cm}$ above the truncus coeliacus. This artery, after passing through the diaphragm, 


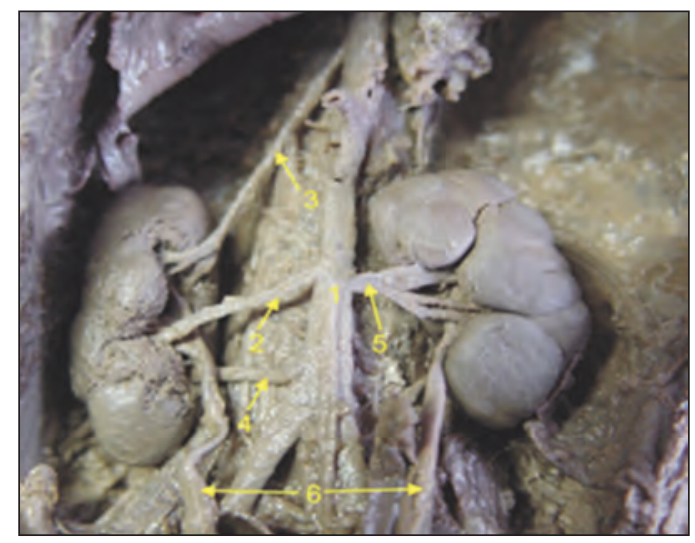

Figure Supernumerary artery (1 - Aorta abdominalis, 2- Arteria renalis dextra, 3 - Arteria renalis poleis superior dextra, 4 - Arteria renalis poleis inferior dextra, 5 - Arteria renalis sinistra, 6 - Ureter).

entered the renal hilus at its upper part and served to vasculate that part of the kidney. The other extra artery, the lower pole artery, separated from the abdominal aorta a little above the site of where it forked into two common iliac arteries, and after briefly passing behind the urethra, it entered the hilus of the kidney in the lower part and served to vasculate its lower pole (Figure). By observation it was noticed that the diameters of the main and the additional renal arteries were approximately the same, but no detailed morphometric measurements of these arteries were made.

\section{Discussion}

There is no unified opinion amongst researchers about the percentage of and where additional renal arteries appear. Double blood supplies, according to data in the literature, occur in a range from $10 \%$ (2) to $23.2 \%$ (3) of cases. One of these arteries is the main one and the other is additional. Goscicka et al. (4), in their analysis of renal arteries in foetuses, found double blood supplies in $19.2 \%$ of cases. The authors mentioned give differing data on the incidence of triple blood supply to the kidneys. Triple blood supply to the kidneys, according to data in the literature, occurs in a range from $1.2 \%$ (2) to $4.5 \%$ (3) of cases. In their analysis of 140 human foetuses, Goscicka et al. (4) recorded triple renal arteries in $2.1 \%$ of cases. Satyapal et al. (3) point out that the kidney may be vascularized by three or more blood vessels, which is recorded in the literature in sporadic cases.

Through an analysis of the material presented in our study, we recorded one unilateral triple renal artery. One of these blood vessels was the main renal artery, whilst the other two were additional arteries, marked as the upper pole artery, originating from the thoracic aorta, and the lower pole artery originating from the abdominal aorta. The case presented corresponds to the presentation given by Norman (5) in his study.

Practice so far has shown that additional renal arteries have major practical importance, because overlooking them during the pre-operative preparation of patients for surgical procedures may be fatal for the patients, especially if laparoscopic methods are used for the procedure. The increasing number of kidney transplants has led in recent times to an increase in the use of laparoscopic surgical techniques, which, with all their advantages, also have failings. That is to say, using these methods reduces the operative field, whereby the risk is increased that variations in the vascularization of the kidneys may lead to a fatal outcome.

\section{Conclusion}

The importance of this study is seen in the fact that anatomic knowledge of variations in the vascularization of the kidneys is of exceptional practical importance. In surgical terms, the upper pole artery represents a major risk because it is frequently located high up, meaning that in most cases the surgeons mistake it for surrounding connective tissue, and unknowingly cut through it, causing thereby massive bleeding, which most often leads to a fatal outcome (6). 
Authors' contributions: Conception and design: ET, AV; Acquisition, analysis and interpretation of data: ET; Drafting the manuscript: AV; Revising it critically for important intellectual content: ET, AV.

Conflict of interest: The authors declare that they have no conflict of interest.

Received: 14 January 2013; Accepted: 11 April 2013 Copyright (C) 2013 by Academy of Sciences and Arts of Bosnia and Herzegovina. E-mail for permission to publish:amabih@anubih.ba

\section{References}

1. Pestemalci T, Mavi A, Yildiz YZ, Yildirim M, Gumusburun E. Bilateral triple renal arteries. Saudi J Kidney Dis Transpl. 2009;20(3):468-70.
2. Bergman RA, Afifi AK, Miyauchi R. Illustrated Encyclopedia of Human Anatomic Variation. Baltimore: Urban and Scdhwarzenberg; 2006.

3. Satyapal KS, Haffejee AA, Singh B, Ramsaroop L, Robbs JV, Kaliden JM. Additional renal arteries: Incidence and morphometry. Surg Radiol Anat. 2001;23(1):33-8.

4. Goscicka D, Szpinda M, Kochan J. Accessory kidney arteries in human fetuses. Ann Anat. 1996;178(6):559-63.

5. Norman DL. An unusual renal arterial anomaly: common origin of arteries to the lower poles. Acta Radiol. 1970;43:505.

6. Merklin RJ, Michels NA. The variant renal and suprarenal blood supply with data on the inferior phrenic, ureteral and gonadal arteries: a review of the literature. J Int Coll Surg. 1958;29:41-76. 